\title{
Kebijakan Kepala Sekolah dalam Membina Akhlak Peserta Didik
}

\author{
Al Munawarah', Fuady Anwar ${ }^{2}$ \\ almunaw20@gmail.com¹ ${ }^{1}$, fuadyanwar@fis.unp.ac.id ${ }^{2}$ \\ Universitas Negeri Padang ${ }^{1,2}$
}

\begin{tabular}{|c|c|}
\hline ARTICLE INFO & \multirow{12}{*}{$\begin{array}{l}\text { ABSTRACT } \\
\text { Penelitian ini dilatarbelakangi oleh kurangnya akhlak } \\
\text { peserta didik, sehingga membutuhkan pembinaan dari } \\
\text { kepala sekolah. Penelitian ini bertujuan untuk melihat } \\
\text { kebijakan kepala sekolah dalam membina akhlak. } \\
\text { Penelitian ini menggunakan metode kualitatif deskriptif } \\
\text { yang berlokasi di SMA Negeri } 12 \text { x11 Kayutanam. Sumber } \\
\text { data diambil melalui observasi, dokumentasi dan } \\
\text { wawancara dengan kepala sekolah, guru PAI, dan peserta } \\
\text { didik. Seluruh data dianalisis melalui reduksi data, } \\
\text { penyajian data, dan penarikan kesimpulan. Hasil penelitian } \\
\text { ini menunjukkan bahwa: (1) Bentuk kebijakan yang } \\
\text { dilaksanakan adalah Shalat zhuhur berjama'ah, shalat } \\
\text { dhuha, dan Kerohanian Islam (Rohis). (2) Dengan } \\
\text { kebijakan ini peserta didik patuh kepada guru, taat } \\
\text { beribadah, hubungan peserta didik dengan guru menjadi } \\
\text { harmonis, dan meningkatkan kedisiplinan serta kerapian } \\
\text { peserta didik. (3) Faktor pendukung pelaksanaan kebijakan } \\
\text { ini adalah adanya partisipasi peserta didik, adanya teladan } \\
\text { yang dapat dicontoh, adanya kerjasama yang baik antara } \\
\text { sekolah dengan orang tua. Sedangkan faktor } \\
\text { penghambatnya yaitu fasilitas kurang memadai, respon } \\
\text { peserta didik berbeda-beda, dan faktor keluarga. }\end{array}$} \\
\hline Article history: & \\
\hline Received, 27 October 2021 & \\
\hline Revised, 11 November 2021 & \\
\hline 0 November 2021 & \\
\hline Keywords: & \\
\hline Kebijakan, Kepala Sekolah, & \\
\hline Pembinaan Akhlak & \\
\hline Clonflict of Interest: & \\
\hline None & \\
\hline Funding: & \\
\hline None & \\
\hline
\end{tabular}

Corresponding Author: Al Munawarah, Department Islamic Education Faculty of Social Science Universitas Negeri Padang, Indonesia, Email: almunaw20@gmail.com, Phone: +62812-6729-2837

\section{Pendahuluan}

Kebijakan merupakan suatu rangkaian konsep dan asas yang menjadi sebuah pedoman dasar rencana dalam pelaksanaan pekerjaan, kepemimpinan serta cara bertindak. Kebijakan ini berbeda dengan sebuah perarturan dan hukum. Jika hukum dapat memaksakan atau melarang suatu perilaku contohnya kewajiban untuk membayar pajak. sedangkan kebijkan hanya menjadi sebuah patokan atau pedoman tindakan yang paling mungkin memperoleh hasil yang diinginkan (Taufiqurokhman, 2014) Karena sifatnya yang kompleks, unik dan khas inilah sekolah sebagai sebuah organisasi yang memerlukan sebuah pemimpin yang mampu mengkoordinasikan hingga pada level tinggi. Pemimpin dalam sekolah adalah kepala sekolah. Maka tidak jarang ditemui bahwa keberhasilan sekolah adalah terdapat pada kepala sekolah. Kepala sekolah yang berhasil ialah yang mampu memahami organisasi sekolah dengan baik serta mampu melaksanakan peran dan fungsinya sebagai kepala sekolah. Sebagai seorang yang diberi tanggung jawab untuk memimpin sekolah (Wahjosumidjo, 2005). 
Pembinaan akhlak yang baik terasa sangat diperlukan karena dengan melihat zaman millenial sekarang ini, banyak terjadi tindakan menyimpang yang menjadi bukti bahwa terjadinya kemerosotan akhlak moral atau kepribadian yang harus segera dibenahi. Menurut Zakiyah Dradjat, (Manan 2017) bahwa salah satu timbulnya krisis akhlak yang terjadi dalam masyarakat adalah karena lemahnya pengawasan sehingga respon terhadap agama kurang. Krisis akhlak tersebut mengindikasi tentang kualitas pendidikan agamanya yang seharusnya memberi nilai spiritual namun justru tidak memiliki kekuatan karena kesadaran yang kurang dalam beragama.

Banyak faktor yang mempengaruhi munculnya kenakalan pada anak atau sudah bisa disebut remaja untuk usia SMA/MAN. Beberapa faktor di antaranya adalah pendidikan dalam keluarga, pergaulan dalam masyarakat, teman bermain, media sosial, dan masih banyak lagi. Dengan melihat berbagai macam tindakan yang menyimpang dari norma seperti yang sudah dijelaskan di atas, menjadi faktor pendorong bahwasanya pendidikan akhlak sangat diperlukan, agar mampu meluruskan kembali atau menjadi benteng bagi anak didik untuk terhindar dari tindakan yang tidak semestinya.

Tujuan penelitian ini adalah pertama Untuk mengetahui bentuk-bentuk kebijakan kepala sekolah dalam membina akhlak peserta didik di SMA N 1 2x11 Kayutanam. Kedua, Untuk mengetahui tujuan dan manfaat pembinaan akhlak dalam kebijakan kepala sekolah di SMAN 1 2x11 Kayutanam. Ketiga, Untuk mengetahui kendala yang ditemui kebijakan kepala Sekolah dalam proses pembinaan akhlak peserta didik di SMA N 1 2x11 Kayutanam.

Manfaat penelitian ini secara teoritis adalah penelitian ini digunakan untuk menambah wawasan dan pengetahuan tentang pembinaan akhlak. Selain itu penelitian ini dapat bermanfaat untuk mengetahui bagaimana kebijakan kepala sekolah dalam pembinaan akhlak peserta didik. Peneliti juga berharap penelitian ini dapat memberikan sumbangan pemikiran dalam memperkaya konsep belajar dalam pembelajaran pendidikan agama Islam. Penelitian ini diharapkan dapat bermanfaat bagi pengembangan pengetahuan tentang pembinaan akhlak peserta didik.

\section{Tinjauan Pustaka}

\section{a. Kepala Sekolah}

Kebijakan kepala sekolah adalah hasil keputusan-keputusan yang dibuat secara arif dan bijaksana oleh kepala sekolah dengan kemampuan menggerakkan segala sumber yang ada pada suatu sekolah sehingga dapat didayagunakan secara maksimal untuk seseorang atau sekelompok orang guna untuk mencapai tujuan yang diinginkan dan ditetapkan dengan melangkah lebih maju ke masa depan (Wahjosumidjo, 2002).

Syarat-syarat kepala sekolah adalah sebagai berikut: pertama, Memiliki ijazah yang sesuai dengan ketentuan atau peraturan yang telah di tetapkan oleh Pemerintah. Kedua, Mempunyai pengalaman kerja yang cukup, terutama di Sekolah yang sejenis dengan sekolah yang di pimpinnya. Ketiga, Mempunyai sifat kepribadian yang baik, terutama sikap dan sifat-sifat kepribadian yang di perlukan bagi kepentingan pendidikan. Keempat, Mempunyai keahlian dan pengetahuan yang luas, terutama mengenai bidang-bidang pengetahuan pekerjaan yang di perlukan bagi sekolah yang dipimpinnya. Kelima, Mempunyai ide dan inisiatif yang baik untuk kemajuan dan pengembangan sekolahnya (Dariyanto, 1996).

Fungsi kepala sekolah ada tujuh fungsi, yaitu: Pertama, Kepala sekolah sebagai Edukator. Kedua, Kepala sekolah sebagai Manager. Ketiga, Kepala sekolah sebagai Administrator. Keempat, Kepala sekolah sebagai Supervisor. Kelima, Kepala sekolah sebagai Leader. Keenam, Kepala sekolah sebagai Inovator. Ketujuh, Kepala sekolah sebagai Motivator (Mulyasa, 2009).

Menurut Wahjosumidjo (2006) tugas kepala sekolah adalah sebagai saluran komunikasi, bertanggung jawab dan mempertanggung jawabkan, kemampuan 
menghadapi persoalan, berpikir analitik dan konsepsional, sebagai mediator atau juru penengah, sebagai politisi, sebagai diploma dan pengambil keputusan yang sulit.

\section{b. Kebijakan Kepala Sekolah}

Kebijakan adalah suatu ketentuan dari pimpinan yang berbeda dengan aturan yang ada, yang dikenakan kepada seseorang karena adanya alasan yang dapat diterima untuk tidak memberlakukan aturan yang berlaku (Imron, 2008). Kata "kebijakan" merupakan terjemahan dari kata "policy" yang berarti mengurus masalah atau kepentingan umum, atau berarti juga administrasi pemerintah (Hasbullah, 2015).

Bentuk-bentuk kegiatan pembinaan yang dapat dilakukan guru di Sekolah dengan cara: Pertama, Menumbuh kembangkan dorongan dari dalam, yang bersumber pada iman dan taqwa. Kedua, Meningkatkan pengetahuan tentang akhlak Al-Qur'an lewat ilmu pengetahuan, pengalaman, dan latihan agar dapat membedakan mana yang baik dan mana yang buruk. Ketiga, Meningkatkan pendidikan kemauan, yang nantinya akan bisa mempengaruhi pikiran dan perasaan. Keempat, Pembiasaan dan pengulangan pelaksanaan yang baik. Sehingga peserta didik merasa bahwa perbuatan baik itu menjadi keharusan moral dan perbuatan akhlak terpuji yang akan selalu dilaksanakannya. Kelima, Di dalam Al-Qur'an dijelaskan bermacam-macam cara untuk membentuk akhlak manusia, misalnya shalat, mengajak orang untuk berbuat baik, mencegah perbuatan mungkar, nasihat yang baik, ajakan kepada keutamaannya, kisah-kisah, contoh teladan dan sebagainya ( Farhan, 2017).

\section{c. Pembinaan Akhlak}

Pembinaan merupakan usaha manusia secara sadar untuk membimbing dan mengarahkan kepribadian serta kemampuan anak, baik dalam pendidikan formal maupun pendidikan non formal (Arifin, 2014). Dipahami bahwa pembinaan adalah kegiatan yang mengacu pada usaha untuk melaksanakan, mempertaruhkan dan menyempurnakan sesuatu yang telah ada, guna memperoleh hasil yang lebih maksimal (Hamied Syarif, 1996).

Akhlak merupakan bentuk jamak dari kata Khuluq yang bermakna adat kebiasaan, perangai, tabi'at, watak, adab atau sopan santun dalam agama (Suwito, 2004). Dipahami bahwa akhlak merupakan perwujudan perilaku yang menghubungkan makhluk dengan khalik-nya dan tata nilai dari khalik terhadap makhluk-nya. Akhlak merupakan sifat yang tertanam dalam jiwa yang mendorongnya untuk melakukan perbuatan tanpa memerlukan pemikiran dan pertimbangan (Wathoni, 2020).

Dasar dan tujuan pembinaan akhlak terikat erat dan hampir sama dengan dasar dan tujuan pendidikan Islam. Dasar ideal pendidikan Islam menurut Syafaat, dkk (2008) adalah identik dengan ajaran Islam itu sendiri, yaitu berasal dari Al-Qur'an dan Hadits. Kemudian dasar tadi dikembangkan lebih lanjut dalam pemikiran para ulama.

Tujuan pembinaan akhlak adalah perwujudan takwa kepada Allah, kesucian jiwa, cinta kebenaran, dan keadilan secara teguh dalam tiap pribadi individu (Syukur, 2010). Macam-macam Akhlak Sejalan dengan pengertian akhlak seperti yang telah dikemukakan di atas, berarti apabila daya dan kemampuan yang telah tertanam dalam jiwa itu melahirkan akhlak yang tidak baik (buruk) maka timbullah akhlak yang tercela. Macammacam akhlak diuraikan sebagai berikut: Pertama, Akhlak Terpuji. Kedua, Akhlak Tercela.

\section{Metode}

Jenis penelitian ini adalah penelitian kualitatif yaitu penelitian yang berusaha menggambarkan objek penelitian yaitu, fakta-fakta, sifat-sifat, hubungan antar kejadian dengan terstruktur, konkret dan akurat sehingga mendapat pemahaman yang mendalam, kemudian dijelaskan secara rinci dalam bentuk tulisan yang bersifat naratif. Selanjutnya sebagai bukti penulis juga mengabadikan seluruh kegiatan yang dilakukan seperti 
wawancara langsung dengan informan, aktivitas belajar peserta didik, dan peran guru PAI dalam membentuk karakter peserta didik (Anggito, 2018 dan Nazir, 2011).

Lokasi penelitian ini adalah di SMA Negeri 1 2x11 Kayutanam yang terletak di jalan Padang- Bukittinggi Kecamatan 2x11 Kayutanam Kabupaten Padang Pariaman. Adapun yang dijadikan informan dalam penelitian ini adalah kepala sekolah SMA Negeri1 2x11 Kayutanam, Guru Pendidikan Agama Islam SMA Negeri 1 2x11 Kayutanam. Instrumen penelitian yang penulis gunakan adalah: Buku catatan, alat rekam, camera. Dalam penelitian ini teknik pengumpulan data yang di gunakan adalah observasi, wawancara, dokumentasi, dan triangulasi. Teknik penganalisisan data yang digunakan adalah reduksi data, penyajian data, penarikan kesimpulan dan verivikasi. Teknik pengabsahan yang digunakan dalam penelitian ini yaitu dengan yang pertama menggunakan teknik triangulasi sumber. Teknik triangulasi sumber yaitu mengecek data yang telah diperoleh melalui beberapa sumber. Kedua, triangulasi teknik yaitu mengecek data kepada sumber yang sama dengan teknik yang berbeda. Ketiga, triangulasi waktu yaitu mengecek data dari sumber yang sama dengan waktu dan kondisi yang berbeda (Rahardjo, 2010).

\section{Hasil dan Pembahasan}

\section{a. Kebijakan Kepala Sekolah dalam Membina Akhlak Peserta Didik di SMA Negeri 1 2x11 Kayutanam}

Kebijakan kepala sekolah dalam pembinaan akhlak ini salah satunya shalat zhuhur berjama'ah. Shalat zhuhur berjama'ah mereka diberi nilai dan nilai tersebut dimasukan kenilai keterampilan di mata pelajaran PAI jadi dengan keluarnya sebuah kebijakan dari kepala Sekolah para peserta didik akan menjadi lebih termotivasi dan takut untuk meninggalkan shalat berjama'ah di sekolah ini, dengan kebijakan kepala sekolah inilah lebih menekankan agar peserta didik lebih disiplin dan termotivasi dalam mengerjakan shalat tanpa ada paksaan dari luar artinya disini memang dari kemauan sendiri dalan beribadah untuk shalat berjama'ah di sekolah.

Kebijakan kepala sekolah setelah dikeluarkan lalu diatur jadwal piket anak, memperingatkan peserta didik supaya bergegas ke mushalla, menasehati mereka yang selalu menunda-nunda shalat, penanggung jawab kegiatan shalat dari kebijakan kepala sekolah, pemberian sanksi kepada peserta didik yang tidak shalat berupa: dijemur di halaman sekolah dan disuruh shalat, selain itu di panggil orang tua dan absensi shalat berjama'ah.

Sebuah aturan atau kebijakan program sekolah dari kebijakan kepala sekolah mengeluarkan punishment terhadap anak yang tidak mengerjakan shalat selain dipanggil orang tua, anak tersebut di jemur di lapangan Sekolah lalu di suruh shalat dengan cara begitu si anak tadi menjadi malu sebab dilihat oleh teman-temannya sehingga si anak ini menjadi takut dan tidak akan meninggalkan shalat.

Dalam shalat berjama'ah ini masih ada peserta didik yang harus kejar dulu supaya mau mengerjakan shalat zhuhur berjama'ah, seperti kebijakan dari kepala sekolah pada pernyataan di atas tadi dibutuhkan hal-hal yang dapat menunjang agar sebuah aturan dari kepala Sekolah sesuai yang diharapkan dan dalam penerapan motivasi shalat berjama'ah ini para guru mata pelajaran PAI bekerja sama dengan kepala Sekolah membuat program dengan sebuah program tersebut Sekolah menyerukan kebijakan berupa nilai tambahan pada mata pelajaran PAI bagi yang mengerjakan shalat berjama'ah secara rutin. Jadi jika peserta didik tersebut harus melaksanakan shalat berjama'ah dan aturan yang lainnya, agar peserta didik memliki keperibadian yang berakhlak mulia dan merasakan ketenteraman dalam hidupnya.

\section{b. Tujuan dan Manfaat Pembinaan Akhlak di SMA Negeri 1 2x11 Kayutanam}

SMA Negeri 1 2x11 Kayutanam terdapat peraturan akademik dari kebijakan kepala sekolah dalam pembinaan akhalak yaitu shalat berjama'ah dan shalat dhuha. Yang mana shalat berjama'ah merupakan kegiatan yang wajib dan rutin dilakukan, tujuan diterapkan 
shalat berjama'ah ini terutama shalat zhuhur berjama'ah supaya peserta didik sadar akan pentingnya shalat dan menjadi terbiasa shalat tepat waktu, sebab shalat berjama'ah ini dilaksanakan bertepatan dengan jam terakhir pelajaran telah habis, yang melatarbelakangi shalat berjama'ah kepala sekolah SMA Negeri 12 x11 Kayutanam mengatakan: Ini karena peserta didik berada di sekolah semenjak jam 07.15 sampai jam 15.00 jadi ada waktu rehat.

Diterapkannya shalat berjama'ah di SMA Negeri 1 2x11 Kayutanamsetelah melakukan wawancara dengan kepala sekolah SMA Negeri 1 2x11 Kayutanam mengeluarkan 2 hal yang melatarbelakangi diterapkannya shalat berjama'ah dalam kebijkaan kepala sekolah di antaranya (hasil wawancara dengan kepala Sekolah SMA Negeri 1 2x11 Kayutanam Ibu Dra. Rahmawati, M.Si. tanggal 29 Juli 2021): Peraturan akademik yaitu kebijakan Pemko Pariaman tentang sekolah 5 hari, lamanya peserta didik di sekolah maksudnya mendekati waktu zhuhur dan ashar adanya waktu rehat otomatis anak lebih lama di sekolah dan sehingga bisa mengerjakan shalat berjama'ah di sekolah. Adanya program pendidikan karakter di sekolah ini, yanag mana program pendidikan karakter tersebut bekerja sama dengan para guru pendidikan agama Islam di SMA Negeri 1 2x11 Kayutanam.

Untuk memotivasi peserta didik agar disiplin dalam mngerjakan shalat tanpa disuruh sangat memberikan pengaruh baik dari kebijakan kepala Sekolah tersebut betapa sekolah sangat menekankan peserta didiknya dalam mengerjakan ibadah shalat berjama'ah ini dari program Sekolah tersebut. Kemudian dengan kegiatan ini diharapkan peserta didik terbiasa melaksanakan shalat tepat waktu dapat dilihat bahwa manfaat yang ditimbulkan dari kebijakan kepala sekolah tersebut peserta didik menjadi takut untuk meninggalkan shalat sebab mendapatkan hukuman atau punishmen dari program sekolah dan selain itu tidak lagi peserta didik menunda-nunda dan mengelak dalam mengerjakan shalat (hasil wawancara dengan kepala sekolah SMA Negeri 1 2x11 Kayutanam, Ibu Dra. Rahmawati, M.Si. tanggal 29 Juli 2021).

\section{c. Kendala yang Ditemui dari Kebijakan Kepala Sekolah dalam Membina Akhlak Peserta Didik di SMA Negeri $12 \times 11$ Kayutanam}

Masalah kendala yang di hadapi kepala sekolah dan para guru dalam kebijkan tersebut seperti yang kita lihat dari hasil wawancara dan pengamatan penulis menyimpulkan bahwa anak-anak pasti tidak semua yang patuh dengat sebuah aturan ada juga yang nakal itu sudah menjadi hal yang lumrah, kendalanya di sini mereka ada sebagian peserta didik tidak terbiasa di rumah mengerjakan shalat tepat waktu sehingga sebuah kebiasaan tersebut terbawah ke sekolah dari yang tidak terbiasa menjadi diharuskan untuk terbiasa si anak tersebut akan menjadi terpaksa dalam melaksanakannya terkendala tidak biasa disini sangat berpengaruh pada diri dan itu selalu dibina di sekolah dari kebijakan dan program-program yang sudah di buat oleh Sekolah (hasil pengamatan penulis sewaktu melakukan penelitian tanggal 01 Agustus 2021).

Sebenarnya di SMA Negeri 1 2x11 Kayutanam ini penulis melihat bagaimana guru-guru dan kepala sekolah disana sudah berusaha semaksimal mungkin agar program kegiatan yang ada di sekolah ini berjalan sesuai dengan yang diharapkan. Namun terkadang guru juga mendapat kendala ketika mengarahkan peserta didik untuk melaksanakan shalat berjamaah seperti yang di katakan guru agama di sekolah ini, beliau mengatakan terkadang kendala yang muncul dan sering terjadi pada diri peserta didik untuk melaksanakan shalat berjamaah ini siswa yang malas dan juga tidak terbiasa atau kebiasaan dirumah yang selalu menunda-nunda waktu shalat dan pengaruh dari teman. kendala lain yang terdapat di Sekolah seperti mushalla kecil, fasilitasnya kurang cukup karena peserta didiknya sangat banyak.

Dapat di simpulkan dari wawancara tersebut sudah mulai menggambarkan adanya usaha guru dan kepala sekolah dari kebijakan tersebut untuk membina peserta didik dalam menjalankan program kebijakan yang sudah dibentuk, sebenarnya memang tidak terdapat kendala tapi ada sebagian peserta didik yang harus dibina mendapatkan perhatian khusus berupa: Memperingatkan peserta didik supaya bergegas ke mushala, Menasehati mereka yang selalu menunda-nunda shalat dan Diberikan sanksi kepada 
peserta didik yang tidak shalat sanksinya berupa: dijemur di halaman sekolah dan disuruh shalat. Di luar ganjaran punishment yang diberikan oleh sekolah terhadap peserta didik yang tidak melaksanakan shalat berjamaah kebijakan kepala sekolah dan guru mata pelajaran agama juga membina peserta didiknya supaya shalat berjamaah.

Dari hasil wawancara tersebut dapat diketahui bahwa kebijakan kepala sekolah dan juga program pendidikan karakter dari guru agama tersebut membuat sebagian peserta didik menjadi terbiasa dalam mengerjakan shalat berjamaah ini dan yang membuat peserta didik menjadi termotivasi menjadi semangat dalam mengerjakan shalat ini mereka diberi apresiasi dengan nilai tambahan pada mata pelajaran agama sehingga tidak ada lagi peserta didik yang tidak mau meninggalkan shalat tersebut.

\section{d. Upaya Guru PAI dalam Mengatasi Kendala dalam Membina Akhlak Peserta Didik di SMA Negeri $12 \times 11$ Kayutanam}

Dalam mengatasi kendala yang ditemukan dari pembinaan akhlak, guru PAI berusaha untuk menemukan solusi terbaik agar program kebijakan ini dapat berjalan dengan baik dan nilai-nilai akhlak dapat ditanamkan kepada peserta didik. Berdasarkan hasil penelitian yang peneliti lakukan di SMA Negeri 1 2x11 Kayutanam ada beberapa kendala yang menjadi faktor penghambat dari program kebijakan kepala sekolah dalam menanamkan nilai-nilai akhlak. Solusi yang dilakukan guru PAI dalam mengatasi faktor penghambat yaitu peserta didik boleh shalat berjama'ah di kelas dan di masjid terdekat. Dalam mengatasi mushalla kecil yang tidak sebanding dengan jumlah peserta didik. Guru PAI mewajibkan peserta didik yang shalat di mushalla sekolah hanya kepada peserta diidk yang belajar PAI pada hari itu, selebihnya boleh shalat di kelas masing-masing maupun di masjid terdekat. Solusi ini dilakukan supaya peserta didik tidak antri dalam beribadah dan bisa beribadah dengan tepat waktu.

Solusi terkait dengan adanya peserta didik yang malas dalam melaksanakan kegiatankegiatan yang mendukung program kebijakan dalam menanamkan nilai-nilai akhlak. Dalam mengatasi hal tersebut guru PAI memberikan hukuman kepada peserta didik yang tidak melaksanakan kegiatan yang ada. Guru PAI memberikan hukuman sesuai dengan kesalahan yang mereka lakukan seperti tidak membawa Al-Qur'an, mereka disuruh berdiri didepan kelas. Tidak mengunakan pakaian muslim dan muslimah baju mereka akan dicoret, tidak shalat berjama'ah akan berdampak kepada nilai akhir PAI. Solusi tekait dengan alokasi waktu pembelajaran PAI yang tidak cukup, guru PAI memberikan jam tambahan pembelajaran PAI diluar jam pembelajaran normal. Penambahan jam ini dilakukan untuk materi yang membutuhkan praktek.

\section{Simpulan}

Kebijakan kepala sekolah dalam meningkatkan akhlak peserta didik tertuang dalam beberapa hal, yaitu melaksanakan program sasaran mutu dan menerapkan kegiatan yang bersifat keagamaan. Program sasaran mutu tersebut memiliki tujuan agar peserta didik berbudaya dalam olah rasa, karsa dan cipta. Unggul dalam bidang akademis dan non akademis. Disiplin tertib kerja, tertib waktu dan tertib administrasi. Inovatif dalam pengembangan kreativitas. Peserta didik memiliki perilaku takwa atau mampu menjalankan ajaran agamanya. Amanah: Dapat dipercaya, jujur: bersikap dan bertindak sesuai hati nurani, dan antusias: mempunyai semangat dalam mewujudkan tujuan. Sedangkan kebijakan dalam bentuk kegiatan yang bersifat keagamaan meliputi: Shalat zhuhur berjamaah, shalat dhuha, rohis, mengadakan pengajian kelas, dan melaksanakan mentoring.

Dalam pelaksanaan kebijakan kepala sekolah dalam meningkatkan akhlak peserta didik tentunya ada hasil yang dicapai sebagai bentuk keberhasilan meningkatkan akhlak peserta didik. Adapun hasil yang dicapai dari pelaksanaan kebijakan kepala sekolah tersebut adalah sebagai berikut menumbuhkan kesadaran diri peserta didik dalam beribadah, menciptakan hubungan yang harmonis antara peserta didik dengan guru, meningkatkan kedisiplinan, meningkatkan kepatuhan terhadap guru, kerapian peserta didik dalam berpakaian. 
Kebijakan kepala sekolah masih cukup efektif dalam meningkatkan akhlak peserta didik dengan adanya beberapa faktor pendukung seperti adanya fasilitas yang memadai, partisipasi peserta didik dalam penerapan kebijakan kepala sekolah, adanya kerjasama yang baik antar personil sekolah dalam melaksanakan kebijakan, kesamaan visi dan misi, adanya kerjasama yang baik antara Sekolah dengan orang tua peserta didik, adanya bimbingan dari kakak kelas dan alumni. Selain faktor pendukung tentunya ada faktor penghambat, adapun faktor penghambat kebijakan kepala sekolah dalam meningkatkan akhlak peserta didik adalah sebagai berikut: Adanya respon peserta didik dalam memahami kebijakan kepala sekolah, terbentuknya jadwal kegiatan, faktor keluarga, dan adanya perbedaan agama.

\section{Referensi}

Ali Imron. (2008). Kebijaksanaan Pendidikan di Indonesia Proses, Produk dan Masa Depannya. Jakarta: Bumi Aksara

Arifin. (2014). Penelitian Pendidikan: Metode dan Paradigma baru. Bandung: PT. Remaja Rosdakarya

Anggito, Albi dan Johan Setiawan. 2018. Metodologi Penelitian Kualitatif. CV Jejak

Daryanto. M. (1996). Administrasi Pendidikan. Jakarta: Rineka Cipta

Farhan. (2017). Strategi Guru PAI Dalam Pembinaan Akhlak Al-Karimah peserta didik di SMAN Manga Baru Kabupaten Musi Rawas. An-Nizom

H.M. Hasbullah. (2015). Kebijakan Pendidikan Dalam Perspektif Teori, Aplikasi, dan Kondisi Objektif Pendidikan Di Indonesia. Jakarta: PT. Raja Grafindo

Mulyasa. (2006). Menjadi Kepala Sekolah Profesional. Bandung. Remaja Rosda Karya

Nazir, M. (2011). Metode Penelitian ( R. Sikumbang (od.); Ketujuh). Ghalia Indonesia

Rahardjo, H. M. (2010). Triangulasi dalam Penelitian Kualitatif. Universitas Islam Negeri Maulana Malik Ibrahim Malang.

Syaepul, Manan. (2017). Pembinaan Akhlak Mulia Melalui Keteladanan dan Pembiasaan. Universitas Pendidikan Indonesia

Syukur, Amin. (2010). Studi Akhlak. Semarang: Walisongo press

Syafaat. (2008). Peranan Pendidikan Agama Islam dalam Mencegah Kenakalan Remaja. Jakarta: Rajawali Press.

Taufiqurrahman. (2014). Kebijakan Publik: Pendelegasian tanggung jawab negara kepada preseiden selaku penyelenggara pemerintahan.

Wahjosumidjo. (2005). Kepemimpinan Kepala Sekolah, Tinjauan Teori dan Permasalahannya. Jakarta: PT. Raja Grafimdo Persada

Wahjosumidjo. (2002). Kepemimpinan Kepala Sekolah. Jakarta: PT. Raja Grafindo Persada 